\title{
Mangrove Restoration and Regeneration Monitoring in Gulf of Kachchh, Gujarat State, India, Using Remote Sensing and Geo-Informatics
}

\author{
Ravi Upadhyay', Nischal Joshi' ${ }^{1}$, Atul Chandrakant Sampat ${ }^{1}$, Arun Kumar Verma1, \\ Ajay Patel2, Vijay Singh2 ${ }^{2}$ Jaydipsinh Kathota ${ }^{2}$, Manik H. Kalubarme ${ }^{2 *}$ \\ ${ }^{1}$ Gujarat Ecological Commission (GEC), Forest and Environment Department, Government of Gujarat, \\ Gandhinagar, India \\ ${ }^{2}$ Bhaskarcharya Institute for Space Applications and Geo-Informatics (BISAG), Department of Science \& \\ Technology, Government of Gujarat, Gandhinagar, India \\ Email: ravi@geciczmp.com, ${ }^{*}$ mhkalubarme@gmail.com
}

Received 13 January 2015; accepted 28 March 2015; published 31 March 2015

Copyright (C) 2015 by authors and Scientific Research Publishing Inc.

This work is licensed under the Creative Commons Attribution International License (CC BY).

http://creativecommons.org/licenses/by/4.0/

(c) (i) Open Access

\section{Abstract}

Indian coast harbors richly diverse and critical coastal habitats like coral reefs and mangroves. Mangroves form one of the most important ecosystems of coastal and marine areas. It safeguards the ecology of the coastal areas and provides livelihood opportunities to the fishermen and pastoral families living in these areas. In real sense, mangrove is the Kalpvriksh (divine tree which fulfills all the desires) for the coastal communities. The restoration and plantation of mangroves have received a lot of attentions worldwide. To assess the impact of mangrove plantation activities and to monitor the mangrove regeneration and restoration in various villages, a joint study under the Integrated Coastal Zone Management Project (ICZMP) was taken up by Gujarat Ecology Commission (GEC) and Bhaskaracharya Institute for Space Applications and Geo-Informatics (BISAG) in the Gulf of Kachchh, Gujarat State. The major objective of this study was to monitor the increase in mangrove cover in coastal areas of Gulf of Kachchh using the Indian Remote Sensing Satellite data of 2005, 2011 and 2014. The mangrove regeneration was monitored using multi-temporal Indian Remote Sensing Satellite (IRS) LISS-III and LISS-IV digital data covering Gulf of Kachchh region. The multi-temporal IRS LISS-III data covering Gulf of Kachchh of October-2005, November2011 and LISS-IV data of April-2014 was analyzed. The mangrove density and mangrove area in different talukas was estimated based on the analysis of IRS LISS-III digital data. The mangroves have been delineated based on the pink colour observed on satellite images and the area was estimated in the Geographic Information System (GIS) environment. The taluka or block-level man-

${ }^{*}$ Corresponding author.

How to cite this paper: Upadhyay, R., Joshi, N., Sampat, A.C., Verma, A.K., Patel, A., Singh, V., Kathota, J. and Kalubarme, M.H. (2015) Mangrove Restoration and Regeneration Monitoring in Gulf of Kachchh, Gujarat State, India, Using Remote Sensing and Geo-Informatics. International Journal of Geosciences, 6, 299-310. http://dx.doi.org/10.4236/ijg.2015.64023 
grove areas were estimated and changes in the areas were monitored during the period of six years from 2005 to 2011. It was observed that the areas where mangrove regeneration activities were carried out with active participation of Community Based Organizations (CBOs), mangrove density as well as mangrove area have substantially increased in the Gulf of Kachchh region.

\title{
Keywords
}

\author{
Remote Sensing, Geo-Informatics, Mangrove Ecosystem, Change Monitoring, Indian Remote \\ Sensing Satellite, Mangrove Regeneration, Community Based Organizations (CBOs)
}

\section{Introduction}

Since the 2004 tsunami, mangrove restoration has become a priority for national as well as State governments in their quest to provide security against sea storms and other natural hazards. The restoration and plantation of mangroves have received a lot of attention worldwide. The awareness regarding the ecological and economic importance of mangroves has grown through the years. As a result, numerous countries are engaged to restore this valuable resource, as reflected by an increasing number of publications and workshops dedicated to this subject (e.g. [1]-[3]). Gujarat has the second largest mangrove cover (1046 sq. km) of the country (4639 sq. km) [4]. The mangrove cover of the state is distributed over four regions viz. Kori creeks (74.1\%), Gulf of Kachchh (15.2\%), Saurashtra (10.1\%) and South Gujarat (0.6\%), covering 11 coastal districts, unevenly distributed over these four regions [4]. There are a substantial number of plantation and restoration projects in Gujarat in which mangroves are planted on intertidal mudflats. Over $130 \mathrm{sq}$. $\mathrm{km}$ of inter-tidal mudflats has been afforested by the Gujarat Forest department from first five-year plan till year 1998-99 [5].

\subsection{Importance of Mangrove Ecosystem}

It is well known that coastal population succumbs to disasters of cyclones and Tsunamis, incurring heavy losses to their properties and live-stock. Mangrove plantation along the coast serves as a barrier to cyclones and Tsunamis and protects the people living in Coastal areas. Mangroves are considered as one of the fragile ecosystem in coastal areas. Mangroves are unique plants capable of surviving under extreme saline environment. Mangroves are evergreen trees and shrubs that grow in saline coastal waters in tropics and also sometimes in subtropics, mainly between $25^{\circ} \mathrm{N}$ and $25^{\circ} \mathrm{S}$. The mangrove ecosystem is highly productive and plays critical role in economic and social development. Mangroves not only have environmental benefits like purifying water, they act as a buffer zone between land and sea and protect land from erosion and play an invaluable role as nature's shield against cyclones, ecological disasters and a protector of shorelines.

\subsection{Characteristics of Gujarat Coastline}

The State of Gujarat enjoys the distinction of having the longest coast line in the country. It is more than 1650 $\mathrm{km}$ and extends right from Jakhau in Kachchh District to Umargam in Valsad district. There are two prominent indentations in this stretch namely the Gulf of Kachchh and the Gulf of Khambhat. The coastal environment of India plays a critical role in the economy of the nation by virtue of its resources and ecosystems such as mangroves, coral reefs, salt marshes, sand dunes, estuaries etc. Gujarat coast has about 1.6 lakh sq. km on the continental shelf. The coast, due to its varied physiographic features, geomorphology, coastal processes and river discharge into the sea, provides a wide variety of coastal features. Based on the distinct variation in the land form categories, the Gujarat coast has been broadly classified into five regions:

1) The Rann of Kachchh, 2) Gulf of Kachchh, 3) The Saurashtra Coast, 4) Gulf of Khambhat, and 5) The South Gujarat Coast. The coast lines of the Gulf of Khambhat and Kachchh together form about $65 \%$ of the coast line of the state. The Rann of Kachchh is a saline desert flooded by the monsoon but remains dry for the rest of the year. There are two major creeks which connect the Rann: Surajbari creek in the Little Rann and Kori creek in the Great Rann. The Gulf of Kachchh has an area of 7350 sq. km stretching in the east-west direction and about $170 \mathrm{~km}$ long. The shore line of the Gulf of Kachchh has extensive mudflats and mangroves. 


\subsection{Role of Remote Sensing and Geo-Informatics}

Remote sensing technique due to its synoptic, multi-temporal, coverage and multi-spectral ability in whole range from optical to microwave regions can effectively act as tool par excellence providing advance and reliable information on mangrove extent and status of its growth along the coastal areas. The reflectance pattern of vegetation in visible \& NIR spectral region give information on condition of vegetation cover.

Gujarat Ecology Commission (GEC) along with Bhaskaracharya Institute for Space Applications and GeoInformatics (BISAG) carried out mapping of mangroves in the coastal districts of Gujarat State using Indian Remote Sensing Satellite (IRS) LISS-III digital data of the 2006-07 period [6]. The maps have been interpreted at 1:10,000 scale and the mangroves have been classified into two density classes namely, dense and spares mangroves. Mangrove atlas for 13 coastal districts with 35 coastal talukas in Gujarat, have been prepared. The comparison of mangrove area estimates carried out by BISAG and Forest Survey of India (FSI) indicates a net increase in the area under mangrove cover. The assessment by BISAG, has recorded $996.3 \mathrm{sq}$. km under mangrove cover, which shows a rise of $88 \mathrm{sq}$. $\mathrm{km}$. In addition to the existing Mangrove cover, the present assessment also gives the availability of potential area of $1153 \mathrm{sq}$. km, where mangrove regeneration program can be taken up.

Classification and mapping of the mangroves in Sunderban Biosphere Reserve (SBR) in the West Bengal province of India using IRS 1D LISS-III satellite data, was carried out using different classification approaches, viz., on-screen visual interpretation, supervised and unsupervised classifications [7]. The study showed that four mangrove classes, and eight non-mangrove classes could be delineated using all the three approaches. It was observed that among the three approaches, on-screen visual interpretation yielded higher classification accuracy (91.7\%) compared to supervised (79.9\%) and unsupervised classifications (71.1\%). The results obtained through on-screen visual interpretation showed that all mangrove categories together cover $23.2 \%$ of the total geographical area of SBR, of which the mixed mangrove category covers maximum area (18.3\%).

Mangroves plantation development is largely dependent not only the proper selection of site but also the selection of planting species and planting method. Kachchh district has a large inter-tidal mudflat which is the potential site for mangroves plantation but all these inter-tidal mudflats are not suitable. A study was carried out to provide a preliminary overview of the coastal segment which was suitable for mangroves plantation. The suitable sites for mangrove plantation are identified based on four variables: coastal land use and land cover, coastal geomorphology, mean tidal range and significant wave height [8]. The significant variables leading to identify suitable plantation sites were land use and land cover and coastal geomorphology. The study suggested that number of variables should be considered such as soil water, ground water and sea water salinity, soil pH etc. for more accurate site selection. The study found that the major problems for mangrove plantation are high temperature and evapo-transpiration, low rainfall/freshwater supply and high salinity. The study also demonstrates that the remote sensing derived variables and GIS techniques are highly useful for suitable site selection for mangroves plantation.

\subsection{Integrated Coastal Zone Management Project (ICZM)}

Gujarat Ecology Commission (GEC) is actively involved in the development and design of the Integrated Coastal Zone Management Project (ICZMP) with Forest \& Environment Department (MoEF), which is a World Bank-funded project. GEC has been appointed as the State Project Management Unit (SPMU) of the ICZMP. Under the ICZMP, GEC is working with several Project Executing Agencies (PEAs) to achieve the specific objectives of the project. GEC is also working with Kachchh Forest Circle for mangrove regeneration and conservation. As the SPMU, GEC shall also coordinate among the Project Executing Agencies (PEAs), ensure effective utilization of allocated funds and provide guidelines to the agencies for better implementation of their respective components thereby providing management services for successful operation of the ICZM program. GEC is the implementing agency for Component A-1 of ICZM i.e. Restoration, Plantation and Conservation of Mangrove along the coast of Gulf of Kachchh. The major responsibilities of GEC are as follows:

- Increase the sensitivity, understanding and acceptance of local communities, Government and coastal industries towards the need to protect, conserve and regenerate mangroves.

- Capacity building of coastal communities and staff of Forest Department for community-based mangrove regeneration.

- Increase the mangrove cover in coastal areas of Gulf of Kachchh through extensive plantation of mangroves 
in potential coastal and inland areas.

- Implement eco-development program for villages adjoining the Gulf of Kachchh to increase people’s participation.

\subsection{Restoration and Plantation of Mangrove along the Coast of Gulf of Kachchh Carried out by GEC}

GEC has taken up an area of 75 ha in the year 2010-11 and 75 ha in 2011-12. So far 150 ha have been covered in village Tuna with active participation of Community Based Organisations (CBOs) Tuna Dariakantha Vistar Vikas Samiti. Village Tuna falls in Anjar block of Kachchh district. During 2012-13, an area of 100 ha has been planted. The main role of GEC is to build the capacity of CBOs in various technical aspects of the plantations. GEC facilitates the local CBO in preparing the micro plan and other technicalities. In addition to this, entry point activity has also been planned based on the need of the village keeping in view the environmental issues faced by the village. Kachchh Forest Circle has been roped in to carry out mangrove re-generation through Forest Development Agencies (FDAs) falling within the Kachchh district. FDA Kachchh has carried out mangrove plantation in villages like Lakki, Bhutau in Lakpath block and villages Jangi and Ambaliyara in Bhachau block. A table showing plantation activities at various villages through participatory approach is given in Table 1.

\subsection{Need for Mangrove Restoration}

It has become clear that mangrove restoration activities need to be monitored from the standpoint of their societal values, and how they can contribute to improving the health of coastal ecosystems and conserving biodiversity within the context of integrated coastal area management. Despite recent improvements in mangrove restoration, the state still has large areas throughout the coast that have a potential for mangrove regeneration. The mangrove Restoration Project through public-private partnership was launched in 2007 by Gujarat Ecology Commission [9]. The important issues which have been considered for mangrove restoration along the Gujarat coast are as follows:

Ecological and Livelihood Security: Mangroves form one of the most important ecosystems of coastal and marine areas. They safeguard the ecological security of the coastal belt and also provide livelihood opportunities to coastal communities, especially fishermen and pastoral families.

Increased Degradation: Due to arid/semi-arid climate in the state, there has been an ever-increasing dependency over this natural resource by local communities. Further, coastal erosion, pollution and anthropogenic pressure are also on the rise with large tidal-amplitude and reduction in the fresh-water inflow into the sea. This has adversely affected the survival of mangroves, leading to their degradation.

\subsection{Objectives}

To Increase Mangroves cover, GEC has undertaken Mangrove plantation and regeneration in several coastal villages in the Kachchh district. The major objectives of study on Mangrove Restoration and Regeneration Monitoring in Gulf of Kachchh in Gujarat State are as follows:

- To monitor Restoration, Plantation and Conservation of Mangrove along the coast of Gulf of Kachchh using multi-temporal Indian Remote Sensing Satellite (IRS) data.

- Monitoring of growth of mangrove on different regeneration sites in different villages using multi-date IRS

Table 1. Plantation activities at various villages through participatory approach.

\begin{tabular}{|c|c|c|c|c|}
\hline \multirow{2}{*}{ District name } & \multirow{2}{*}{ Taluka/Village name } & \multicolumn{2}{|c|}{ Plantation achievement/Target (ha) } & \multirow{2}{*}{ Total area (ha) } \\
\hline & & 2010-11 & 2011-12 & \\
\hline \multirow{4}{*}{ Kachchh } & Lakhpat/Lakki & $500 / 500$ & $750 / 750$ & 1250 \\
\hline & Lakhpat/Bhutau & $500 / 500$ & $750 / 750$ & 1250 \\
\hline & Bhachau/Amaliyara & 0 & $300 / 300$ & 300 \\
\hline & Bhachau/Jangi & 0 & $200 / 300$ & 200 \\
\hline Total & & $1000 / 3000$ & $2000 / 2000$ & 3000 \\
\hline
\end{tabular}


satellite data of 2005 and 2011.

- Taluka or block-level area estimation under mangroves using GIS techniques and change monitoring of mangroves during the period of six years from 2005 to 2011.

\section{Study Area}

The Gulf of Kachchh (GOK), a large marine ecosystem in the State of Gujarat, has unique ecosystems like coral reefs and mangroves at its southern coast and mangroves at selected locations along the northern coast. The GOK has tidal amplitude ranging from 3 - $8 \mathrm{~m}$. The developmental activities like construction of ports and human interventions like mining of corals, destruction of mangroves to expand the salt pan activities etc., have extensively damaged the corals and the mangroves in the region. Due to its proximity to the Arabian Gulf, the GOK has attracted establishment of facilities like ports, Single Point Mooring (SPM) stations for handling large amount of crude oil. The gulf is rich in marine wealth and biodiversity. The region was notified as a Marine National Park and Sanctuary (MNPS) in 1982. The map of the Gulf of Kachchh (GOK), showing study area is shown in Figure 1.

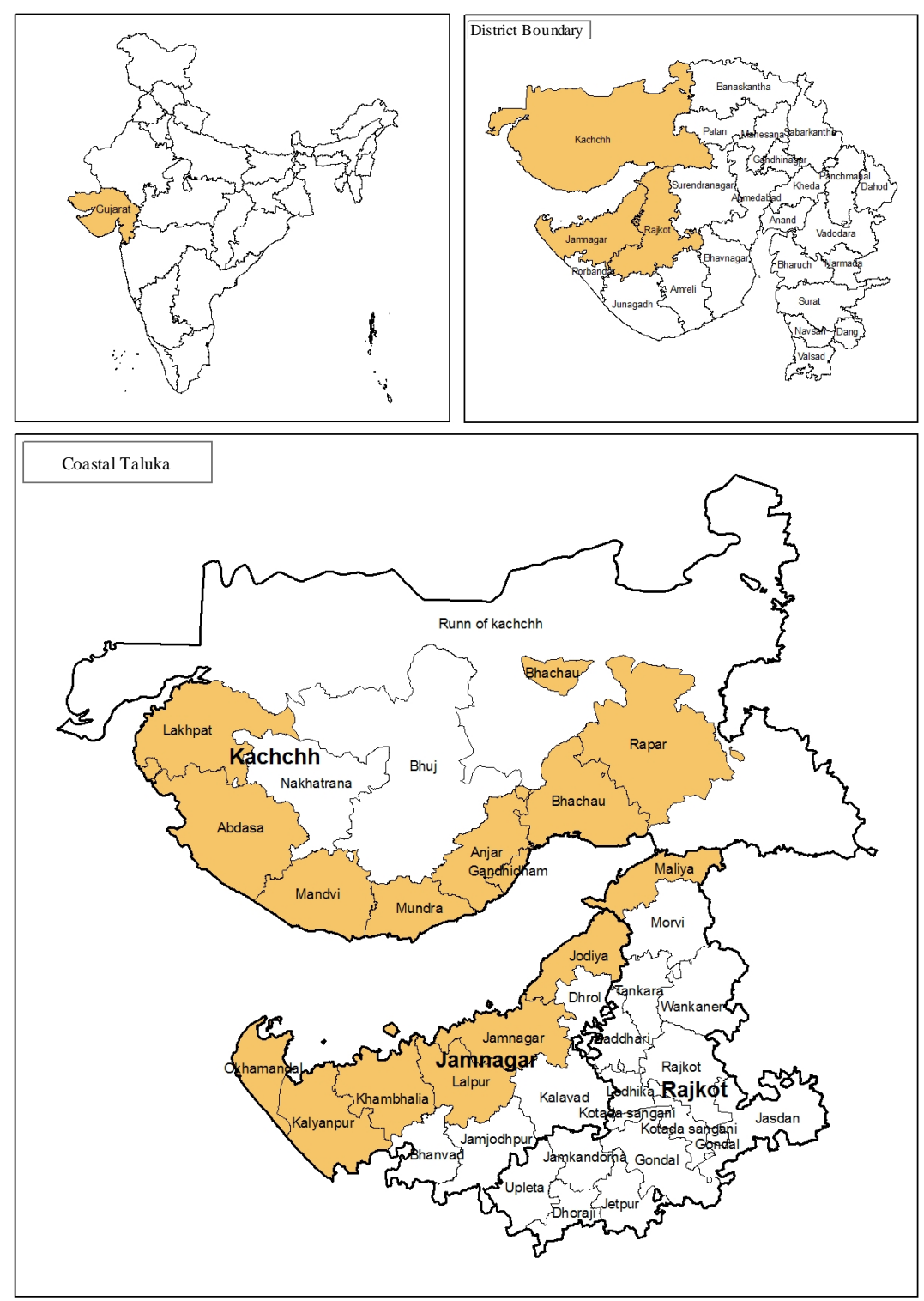

Figure 1. Location map of the Gulf of Kachchh (GOK), in Gujarat State (India). 


\section{Methodology}

\subsection{Indian Remote Sensing Satellite Data Used}

Indian Remote Sensing Satellite (IRS-P6 and IRS-RS2) digital data of for three different time periods, i.e. October-2005, November-2011 and Apri-2014 covering Gulf of Kachchh region were acquired for monitoring \& mapping of mangrove regeneration activity in various villages. The details of IRS digital data acquired are given in Table 2.

\subsection{Mangrove Plantation Carried out by GEC}

The potential sites for mangrove plantation were identified based on the detailed field survey carried out in various villages of different blocks by GEC. One of the site selected in Tuna village of Anjar taluka (block) of Kachhch district is given in Figure 2.

Table 2. Satellite data used in mapping monitoring mangrove regeneration.

\begin{tabular}{cccc}
\hline Sr. No. & Sensor & Path/Row & Date of pass \\
\hline 1. & LISS-III & $89 / 55$ & $14-$ Oct-2005 \\
2. & LISS-III & $89 / 56$ & $14-$ Oct-2005 \\
3. & LISS-III & $90 / 55$ & $18-$ Oct-2005 \\
4. & LISS-III & $90 / 56$ & $18-O c t-2005$ \\
5. & LISS-III & $89 / 55$ & $12-$ Nov-2011 \\
6 & LISS-III & $89 / 56$ & $12-$ Nov-2011 \\
7. & LISS-III & $90 / 55$ & $16-$ Nov-2011 \\
9. & LISS-III & $90 / 56$ & $16-N o v-2011$ \\
10. & LISS-IV & $91 / 56$ & $18-A p r-2014$ \\
\end{tabular}

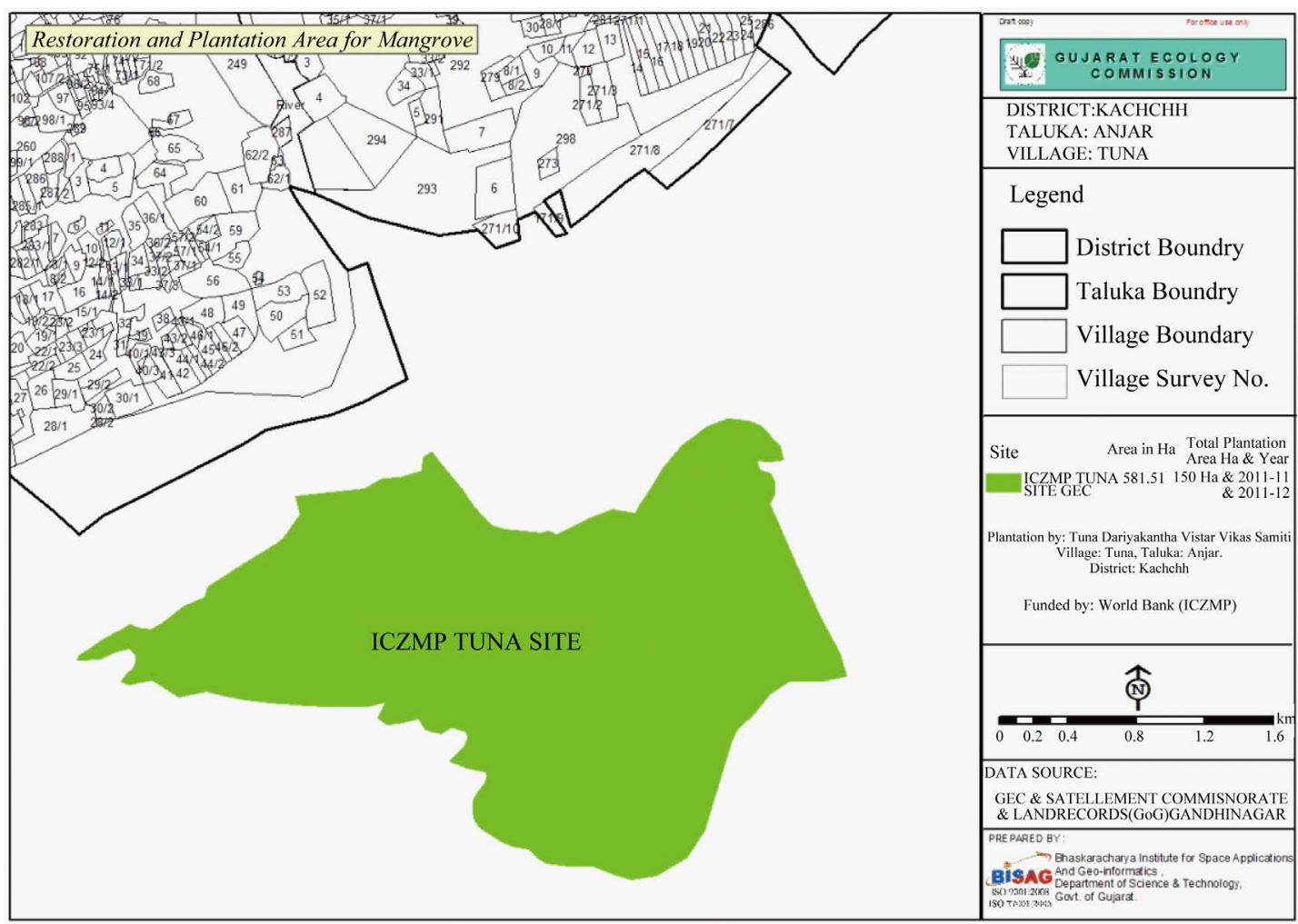

Figure 2. Mangrove plantation site Tuna, Taluka-Anjar (Gulf of Kachchh) identified under ICZM project. 
Local communities are trained in technical aspects so that they are able to carry out various operations like raising of nursery, seed sowing, seedling collection and plantation in the field. After plantation, a constant monitoring is carried out to ensure better survival rate. In addition to monitoring by PEAs, a third part monitoring was also carried out. The field photographs of mangrove seedlings raised in nursery and plantation of mangrove seedlings by local communities by participatory approach are given in Figure 3 \& Figure 4.

\subsection{IRS LISS-III Data Analysis}

IRS LISS-III and LISS-IV digital data covering study area were analyzed and it broadly consists of following steps:

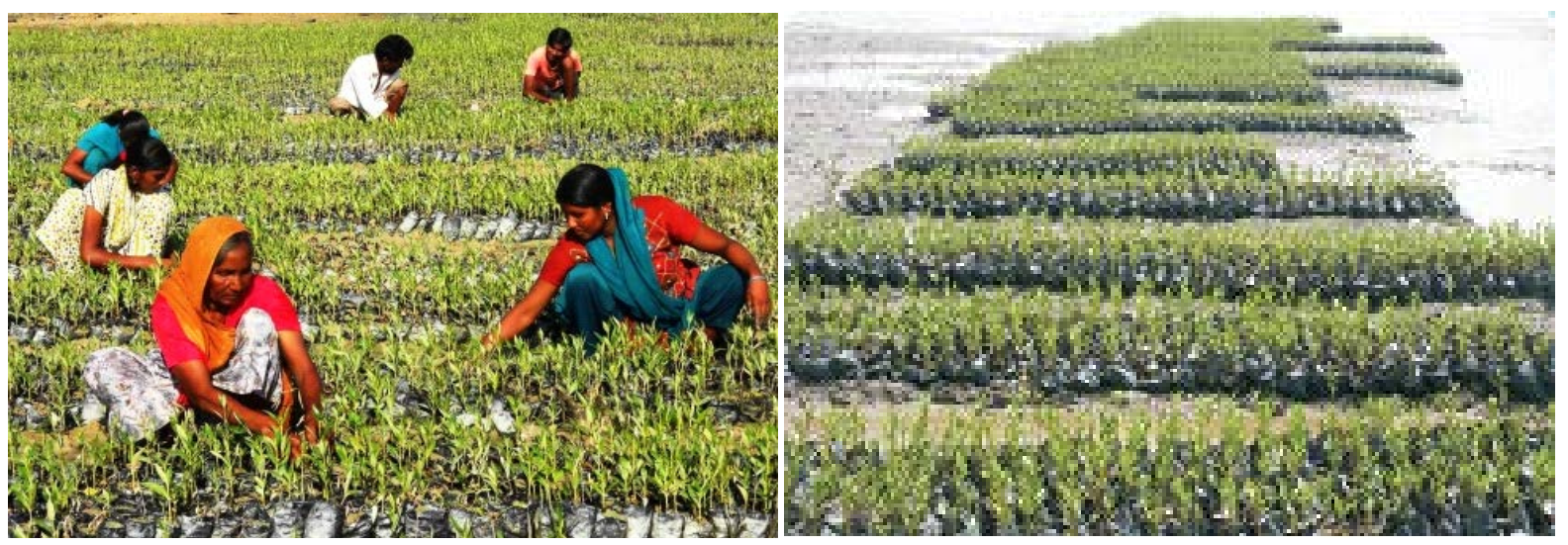

Figure 3. Mangrove seedings raised in nursery for plantation by participatory approach in Gulf of Kachchh.

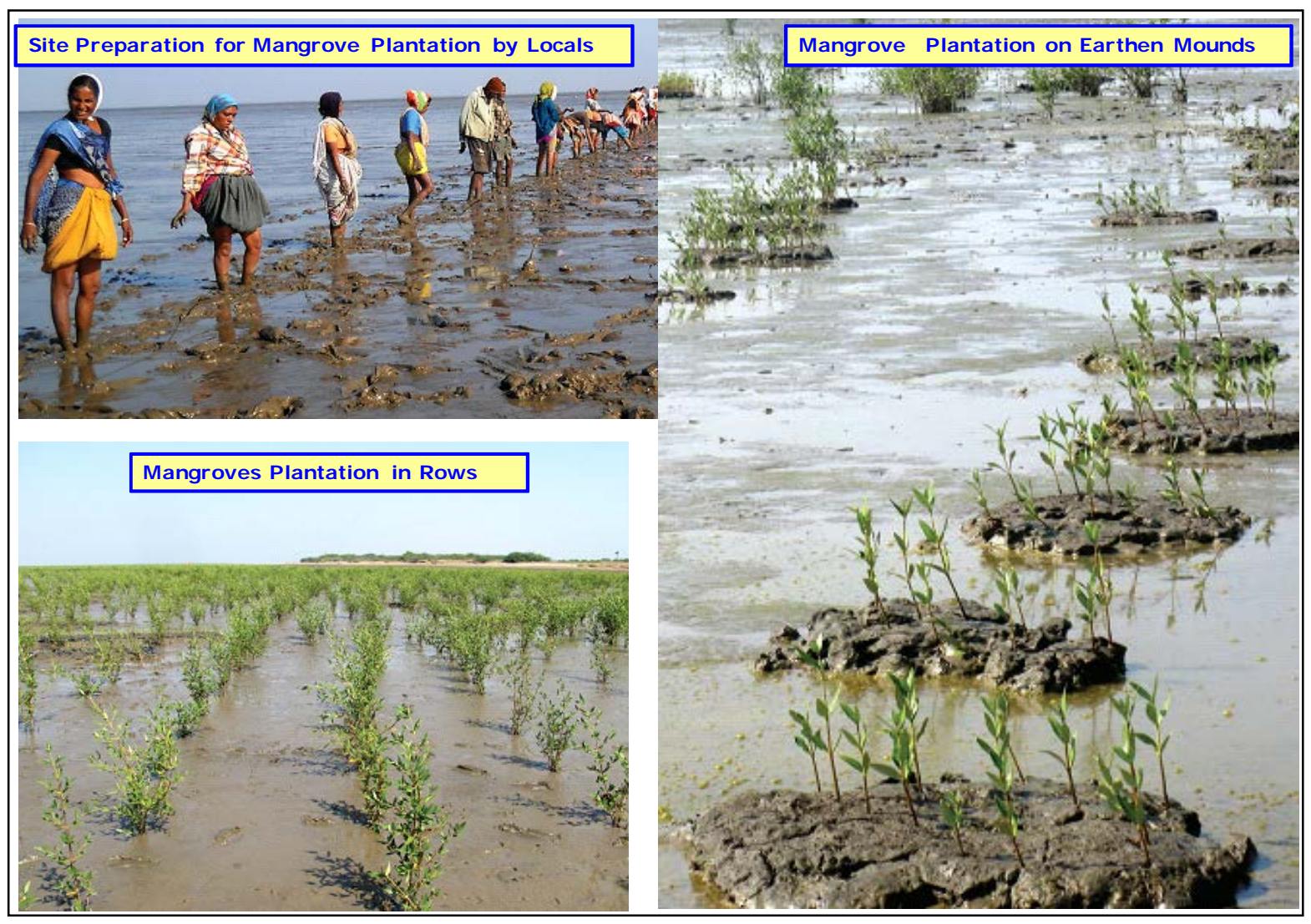

Figure 4. Mangrove plantation by participatory approach in Gulf of Kachchh. 
1) Multi-date data preparation and geo-referencing, 2) administrative boundary superimposing, 3) generation of spatial information in GIS environment at the desired scale, 4) superimposing GPS locations of mangrove sites collected during GT data collection on the registered LISS-III digital data, 5) identification \& delineation of mangrove into different density classes and 6) area estimation under mangroves and change detection in the mangrove vegetation and density.

\subsubsection{Extraction of IRS LISS-III Data for Mangrove Mapping}

IRS LISS-III and LISS-IV digital data of different dates was registered using Ground Control Points (GCPs) identified on image and Global Positioning System (GPS) measurements. The administrative boundaries like district, taluka and village were superimposed on the registered satellite data. From the registered data-set study areas in different talukas was extracted for monitoring mangrove regeneration, mangrove vegetation density as well as area estimation in different coastal taluka. One of the images covering part of Kachchh district along with taluka and village boundaries is given in Figure 5.

\subsubsection{Identification of Potential Sites for Mangrove on IRS LISS-IV Data}

GEC initiated the Community Based mangrove Restoration across ten locations situated in six coastal districts of the Gujarat State through village-level community based organizations. The suitable sites for mangrove plantations across various sites were identified by the GEC and their GPS measurements were recorded. These GPS measurements of various sites were transferred on the IRS LISS-IV images covering various sites for monitoring the mangrove regeneration and growth and density of mangrove using multi-date satellite data. The locations of potential sites identified on IRS LISS-IV satellite images covering part of Jodia taluka in Jamnagar district are given in Figure 6.

\subsubsection{Mangrove Mapping Procedure}

The multi-date satellite LISS-III digital data have been interpreted visually for mapping mangrove cover in the selected villages. Intensity of pink tone observed on LISS-III images was considered as basis for mangrove mapping along the coastal areas. The mangrove mapping was carried out using IRS LISS-III images of 2005 and 2011. The Quantum GIS software was used for mangrove delineation and computation of area. The area under mangrove in Jamnagar and Anjar talukas in Jamnagar and Kachchh districts was estimated for 2005 and 2011 as well as 2014 .

\section{Results and Discussions}

The multi-date Indian Remote Sensing Satellite (IRS-P6) LISS-III digital data of October-2005 and November-

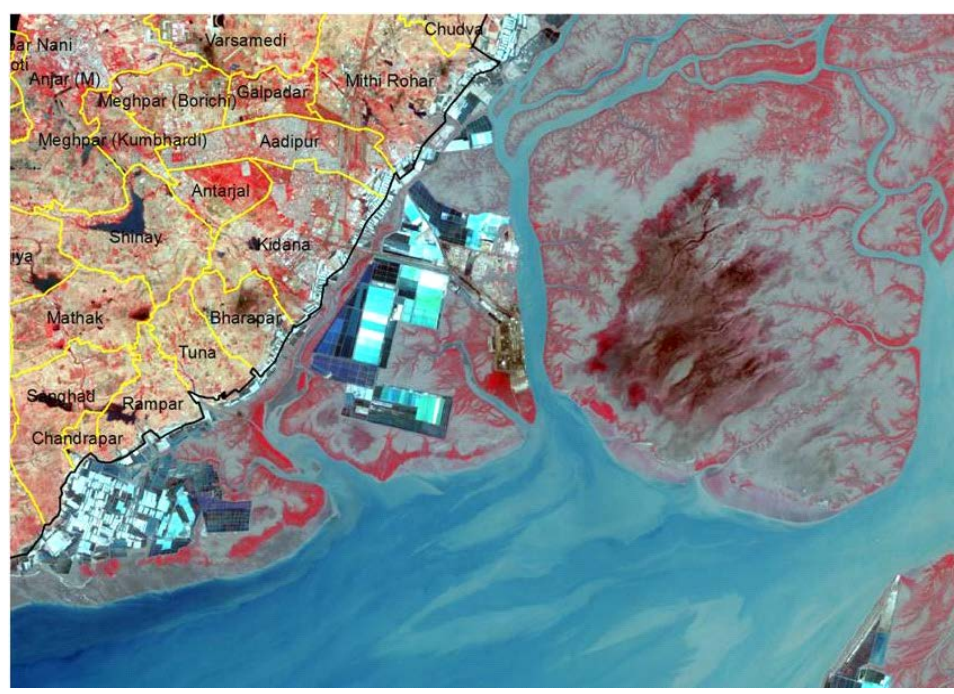

Figure 5. IRS LISS-III image covering part of Kachchh district: 12-Nov2011. 

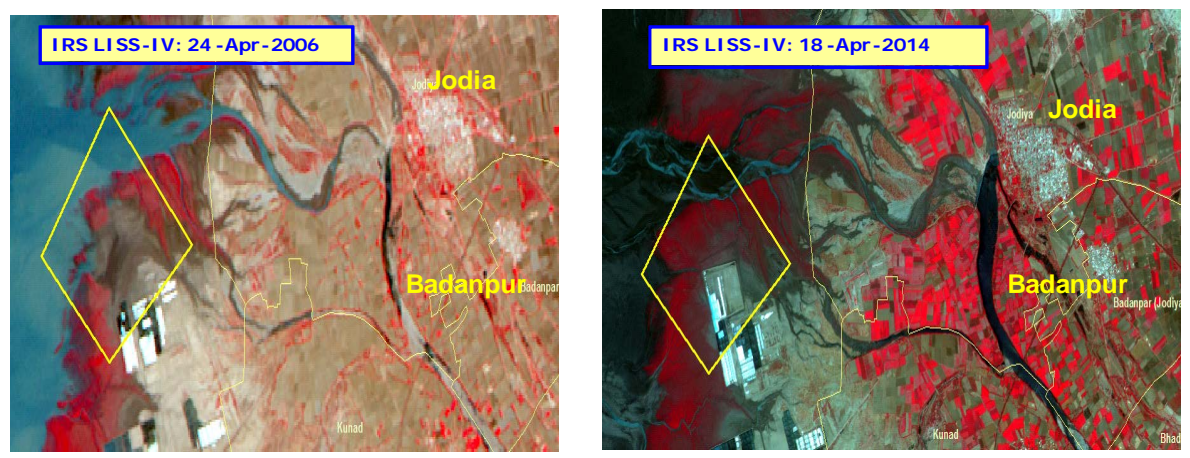

Figure 6. Mangrove regeneration site marked on IRS LISS-IV images near Jodia village.

2011 covering coastal areas of Anjar and Jamnagar talukas were interpreted visually for mapping mangrove cover. In these two talukas extensive mangrove regeneration programme was carried out by the GEC. The areas where mangroves regeneration activity was carried out have been visually interpreted for mapping of mangrove cover based on the intensity of pink tone observed on LISS-III images. The mangroves have been classified into two density classes namely dense mangrove and sparse mangrove based on the intensity of pink tone observed on LISS-III images. On IRS LISS-III False Colour Composites (FCC) mangroves occur in bright red colour if it is in continuous patch. When mangroves are scattered then instead of bright red colour, a light brick red colour may be seen.

\subsection{Mangrove Mapping in Anjar Taluka}

In Anjar taluka, coastal areas adjoining Tuna and Rampart villages were identified for mangrove regeneration under ICZM project by the GEC (Figure 2). The mangrove plantation by participatory approach was carried out by GEC on this selected site. Indian Remote Sensing satellite (IRS-P6) LISS-III data of October-2005 and November-2011 covering Anjar taluka was analysed for mapping and monitoring the mangrove plantation areas. The IRS-P6 LISS-III images of October-2005 and November-2011 covering coastal areas of Anjar taluka is given in Figure 7. The LISS-III image of November-2011 shows large patches of mangroves in the costal areas as compared to October-2005 image. This indicates there is increase in Mangrove area in the Anjar taluka during the period of last 5 to 6 years (2005 to 2011). The area under mangrove was estimated using GIS techniques. The comparison of two satellite images in Figure 7 indicates that the estimated area covering part of coastal areas of Anjar taluka has increased from 11.76 sq. km during October-2005 to 13.42 sq. km during November2011.

\subsection{Mangrove Mapping in Jamnagar Taluka}

In Jamnagar taluka, two areas were studied one covering coastal areas of Rozibet, Jabuda and Khijadiya villages and other covering Sarmet and Bed villages. IRS LISS-III images covering these villages were studied and areas under mangrove were estimated using GIS. The IRS-P6 LISS-III image of October-2005 and November-2011 covering coastal areas of Jamnagar taluka is given in Figure 8. The analysis of two satellite images in Figure 8 indicates that the estimated area covering part of coastal areas of Jamnagar taluka has increased from 78.76 sq. km during October-2005 to 80.66 sq. km during November-2011.

\subsection{Mangrove Mapping in Maliya Taluka}

In Maliya taluka of Rajkot district, coastal areas adjoining Navalakhi, Bodki and Varsamedi villages were identified for mangrove regeneration under ICZM project. The mangrove plantation by participatory approach was carried out by GEC on the selected site. Indian Remote Sensing satellite (IRS-P6) LISS-III data of October-2005 and November-2011 covering Maliya taluka was analysed for mapping and monitoring the mangrove plantation areas. The IRS-P6 LISS-III images of October-2005 and November-2011 covering coastal areas of Maliya taluka are given in Figure 9.

The LISS-III image of November-2011 shows large patches of dense mangroves areas as compared to October- 

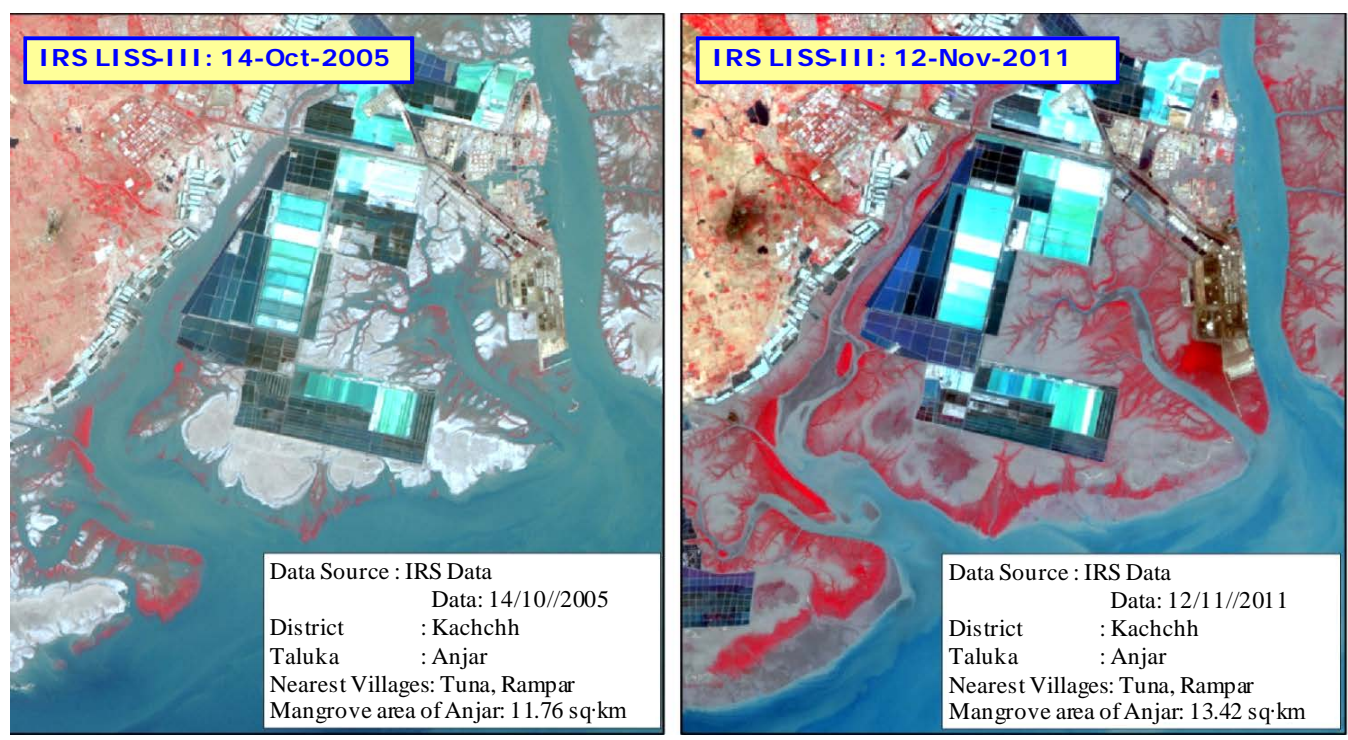

Figure 7. IRS LISS-III images of October-2005 \& November-2011 coving Anjar taluka, Kachchh.
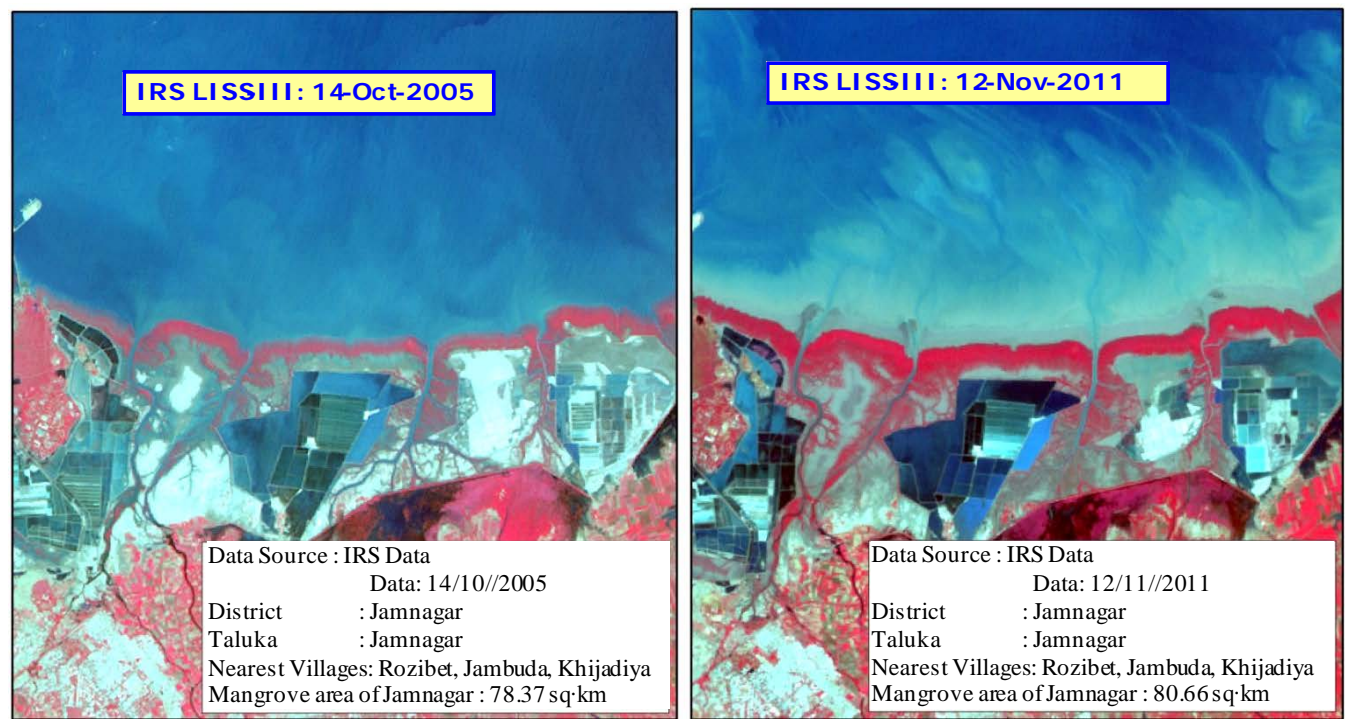

Figure 8. IRS LISS-III images of October-2005 \& November-2011 coving Jamnagar taluka, Kachchh.

2005 image. This indicates there is increase in Mangrove area in the Anjar taluka during the period of last 5 to 6 years (2005 to 2011) mainly due to mangrove regeneration activity carried out by the GEC. The estimated area under mangroves indicates that the estimated has increased from 8.82 sq. km during October-2005 to 22.95 sq. km during November-2011, in the coastal area of Maliya taluka in Rjakot District.

\subsection{Change Monitoring of Area under Mangrove Plantation}

The IRS LISS-III images clearly indicate that the mangrove area is increased substantially in the various taluka of Gulf of Kachchh over the period of 6 years from 2005 to 2011. The results indicated in the Figures 7-9 are tabulated in Table 3 to bring out the increase in mangrove area due to the efforts of mangrove regeneration programme carried out by GEC with active participation of Community Based Organizations (CBOs) in the Gulf of Kachchh region.

The results of present study on change monitoring reveals that mangrove area has considerably increased in study talukas mainly because of the mangrove regeneration activity carried out by the GEC with active partici- 

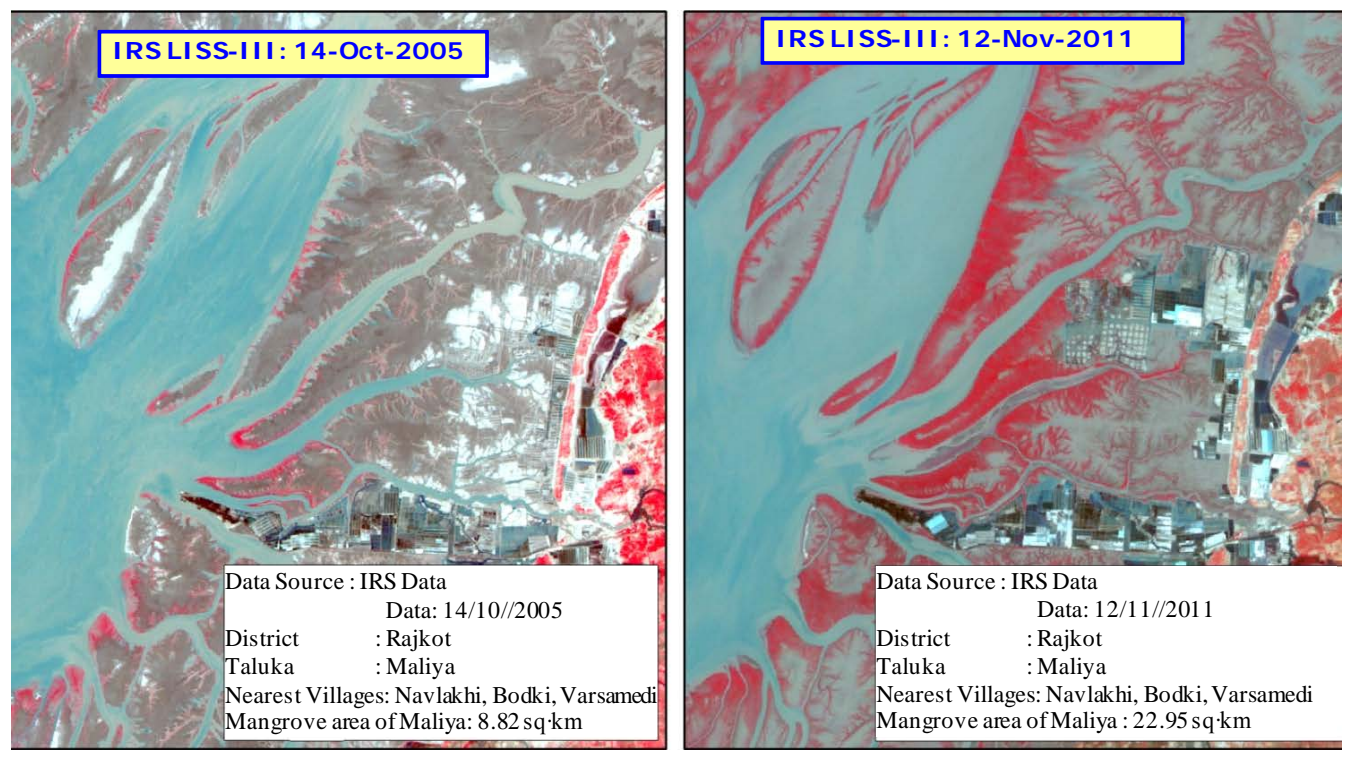

Figure 9. IRS LISS-III images of October-2005 \& November-2011 coving Maliya taluka, Rajkot.

Table 3. Change monitoring of mangrove regeneration activity in Gulf of Kachchh region.

\begin{tabular}{|c|c|c|c|c|}
\hline \multirow{2}{*}{ District } & \multirow{2}{*}{ Taluka } & \multirow{2}{*}{ Mangrove density } & \multicolumn{2}{|c|}{ Mangrove area (ha) } \\
\hline & & & 2005 & 2011 \\
\hline \multirow{3}{*}{ Kachchh } & \multirow{3}{*}{ Anjar } & Dense & 486.7 & 636.9 \\
\hline & & Sparse & 689.3 & 705.2 \\
\hline & & Total & 1176.0 & 1342.1 \\
\hline \multirow{3}{*}{ Jamnagar } & \multirow{3}{*}{ Maliya } & Dense & 272.1 & 790.9 \\
\hline & & Sparse & 609.4 & 1504.1 \\
\hline & & Total & 881.5 & 2295.0 \\
\hline \multirow{3}{*}{ Jamnagar } & \multirow{3}{*}{ Jamnagar } & Dense & 5033.6 & 2423.1 \\
\hline & & Sparse & 2803.6 & 5643.0 \\
\hline & & Total & 7837.2 & 8066.1 \\
\hline
\end{tabular}

pation of Community Based Organizations (CBOs).

This increase in mangrove cover in most of the places is mainly due to the better understanding and acceptance of the need to protect, conserve and regenerate mangroves by the local communities. At the same time, capacity building of coastal communities for community-based mangrove regeneration as part of integrated coastal zone management has helped in substantial increase of the mangrove cover. The other reason is attributed to the fact that as a part of Coastal Zone clearances, most of the coastal industries were required to raise and regenerate mangrove plantations. Monitoring of mangrove regeneration activity was carried out independently by the private sector which enforced strict compliance of the mangrove regeneration guidelines by all the coastal industries which has also helped to increase the mangrove cover in the study areas.

\section{Conclusions}

Gujarat Ecology Commission (GEC) has taken up extensive mangrove restoration in various villages of different blocks in Gulf of Kachchhh with active participation of Community Based Organizations (CBOs) under the Integrated Coastal Zone Management Project (ICZMP) with Forest \& Environment Department (MoEF), which is a World Bank-funded project. To assess the impact of these mangrove plantation activities and to monitor the 
mangrove regeneration and restoration in various villages, a joint study under the ICZM project was taken up by GEC and Bhaskarcharya Institute for Space Applications and Geo-Informatics (BISAG) Monitoring mangrove areas in the Gulf of Kachchh, Gujarat State using Remote Sensing and Geo-Informatics.

The achievements and sustainability of mangrove restoration activity by GEC were monitored by analysing Indian Remote Sensing Satellite (IRS-P6) LISS-III and LISS-IV digital data covering Gulf of Kachchh for the period of 2005 and 2011. Remote sensing data was analyzed using ENVI Software and the mangrove area was delineated using the Quantum GIS software. The changes in mangrove cover over a period six years in the selected coastal areas of different talukas in Gulf of Kachchh were analysed. The results of present study on change monitoring revels that mangrove area has considerably increased in study talukas mainly because of the mangrove regeneration activity carried out by the GEC with active participation of Community Based Organizations (CBOs).

\section{Acknowledgements}

The authors like to express their sincere thanks to Shri T. P. Singh, Director, Bhaskarcharya Institute for Space Applications and Geo-Informatics (BISAG), Department of Science \& Technology, Government of Gujarat, Gandhinagar 382007, for his keen interest and encouragement in successfully executing this project.

The authors are very much thankful to the Forest Department, Government of Gujarat, Chief Conservator of Forest (CCF), Marine National Park (MNP), Jamnagar and Chief Conservator of Forest (CCF), Kachchh, for providing detailed information and logistic support to carry out this study.

Data on plantation sites for mangrove regeneration activities carried out with active participation of Community Based Organizations (CBOs), was provided by Shri Lomesh Brahmbhatt and Shri Ishwar Desai, as well as Project coordinators and community mobilisers, GEC team (Socio-Economic component, ICZM Project), Gujarat Ecology Commission (GEC). The authors sincerely thank them for their kind cooperation and active support to carry out this study.

\section{References}

[1] Field, C.D. (1996) Restoration of Mangrove Ecosystems. International Society for Mangrove Ecosystems, Okinawa.

[2] Field, C.D. (1999) Mangrove Rehabilitation: Choice and Necessity. Hydrobiologia, 413, 47-52.

[3] Khemnark, C. (1995) Ecology and Management of Mangrove Restoration and Regeneration in East and Southeast Asia. Proceeding of the ECOTONE IV, Surat Thani, 18-22 January 1995.

[4] India State of Forest Report (2009) Forest Survey of India. http://www.census2011.co.in

[5] Singh, H.S. (2007) Mangroves in Gujarat (Current Status and Strategy for Conservation). Gujarat Ecological Education \& Research (GEER) Foundation.

[6] Ajay, P., Vijay, S., Mehmood, K., Jaydipsinh, K., Kalubarme, M.H., Pandya, C.H., Joshi, N. and Brahmabhatt, L. (2014) Mapping and Monitoring of Mangroves in Coastal Districts of Gujarat State Using Remote Sensing and GeoInformatics. Asian Journal of Geoinformatics, 14, 15-26.

[7] Nandy, S. and Kushwaha, S. (2011) Study on the Utility of IRS-1D LISS-III Data and the Classification Techniques for Mapping of Sunderban Mangroves. Journal of Coastal Conservation, 15, 123-137.

[8] Mahapatra, M., Ratheesh, R. and Rajawat, A.S. (2013) Potential Site Selection for Mangrove Plantation along the Kachchh District, Gujarat, India Using Remote Sensing and GIS Techniques. International Journal of Geology, Earth \& Environmental Sciences, 3, 18-23.

[9] Gujarat Ecology Commission (2012) Mangrove Restoration through Public-Private Partnership. 86. 